\title{
COMMUNICATIVE-FUNCTIONAL APPROACH IN RUSSIAN TRANSLATION STUDIES: WHERE DOES IT COME FROM?
}

\author{
Vadim V. Sdobnikov \\ Nizhny Novgorod State Linguistic University named after N.A. Dobrolyubov, \\ Nizhny Novgorod, Russian Federation
}

\begin{abstract}
The relevance of the article is conditioned by the vital need to comprehend prerequisites of the communicative-functional approach to translation in Russian translation studies, which, in its turn, will help reveal the inner logic of the development of translation studies, the logical changes of translation scholars' thinking, predetermined by the turns in the science itself as well as define perspectives of Translation Studies development. Grounded on a thorough analysis of the theoretical provisions voiced in the works of the founders of Russian Translation Studies, the article highlights the essence of the communicative-functional approach to translation: unlike a purely linguistic, text-oriented approach, the communicative-functional approach investigates a translation event in the framework of a specific communicative situation within which the translation is done, taking into consideration both linguistic and extralingual factors (e.g. communicative intention of the Source Text Sender, the character of the communicative effect produced on the Target Text Recipient, etc.) that influence the translation process and its outcome. The diachronic analysis of the basic categories and concepts of the communicativefunctional approach is provided, the structure of interlingual and cross-cultural communication is described, the concepts of "communicative intention", "the text's dominant function", "communicative effect" and some others are redefined. The merits of the communicative-functional approach to theoretical investigation and practical realization of various types of translation, including simultaneous interpreting, in specific communicative situations are demonstrated and substantiated.

Key words: communicative-functional approach, linguistic approach, communicative situation, communicative intention, communicative effect, communicative-functional equivalence, act of communication.

Citation. Sdobnikov V.V. Communicative-Functional Approach in Russian Translation Studies: Where Does It Come From? Vestnik Volgogradskogo gosudarstvennogo universiteta. Seriya 2, Yazykoznanie [Science Journal of Volgograd State University. Linguistics], 2017, vol. 16, no. 3, pp. 71-79. DOI: https://doi.org/10.15688/ jvolsu2.2017.3.7
\end{abstract}

УДК 81 '25

Дата поступления статьи: 20.05.2017

ББК 81.18 Дата принятия статьи: 23.06.2017

\section{КОММУНИКАТИВНО-ФУНКЦИОНАЛЬНЫЙ ПОДХОД В РОССИЙСКОМ ПЕРЕВОДОВЕДЕНИИ: ИСТОКИ}

\author{
Вадим Витальевич Сдобников \\ Нижегородский государственный лингвистический университет имени Н.А. Добролюбова, \\ г. Нижний Новгород, Российская Федерация
}

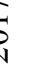

Аннотация. Актуальность статьи обусловлена необходимостью осмысления предпосылок возникновения коммуникативно-функционального подхода к переводу в российском переводоведении, что позволит обнаружить внутреннюю логику развития науки о переводе, закономерные изменения мышления переводоведов, детерминированные этой логикой, и определить возможные пути дальнейшего развития переводоведения. В результате обобщения работ классиков отечественного переводоведения в статье выявлена специфика коммуникативно-функционального подхода: при нем, в отличие от сугубо лингвистического подхода, переводческое событие трактуется как процесс, осуществляемый в рамках коммуникативной ситуации, в которой это событие происходит, и учитываются не только лингвистические, но и экстралингвистические 
факторы (например, коммуникативная интенция автора исходного текста и вид коммуникативного воздействия на получателя перевода), влияющие на ход и результат перевода; рассмотрены возможности интерпретации перевода как коммуникативно-функционального аналога оригинала. Охарактеризован в динамике понятийный аппарат коммуникативно-функционального подхода: описана структура коммуникативной ситуации перевода, определены термины «коммуникативная интенция», «функциональная доминанта текста», «коммуникативный эффект» и некоторые другие. Продемонстрированы возможности применения коммуникативно-функционального подхода в переводческой практике, в частности при синхронном переводе в рамках определенной коммуникативной ситуации.

Ключевые слова: коммуникативно-функциональный подход, лингвистический подход, коммуникативная ситуация, коммуникативная интенция, коммуникативный эффект, коммуникативно-функциональная эквивалентность, акт коммуникации.

Цитирование. Sdobnikov V. V. Communicative-Functional Approach in Russian Translation Studies: Where Does It Come From? // Вестник Волгоградского государственного университета. Серия 2, Языкознание. 2017. - T. 16, № 3. - C. 71-79. - DOI: https://doi.org/10.15688/jvolsu2.2017.3.7

\section{Introduction}

According to the communicative-functional approach (CFA), translation is viewed as a human activity embedded into a situation of direct communication between a source language (SL) Sender and a target language (TL) Recipient or indirect communication between a TL recipient and a SL sender though a target text (TT). A TT recipient is any person who needs the text to perform his / her activity and to satisfy his / her specific needs. Accordingly, this implies consideration of a number of extra-lingual factors influencing the outcome of the translation activity such as: the nature of the activity performed by a TT recipient, the way in which the TT will be potentially used, the needs of the TT recipient, his / her expectations, etc. A thorough analysis of these factors enables a translator to formulate the translation goal and to choose a translation strategy which is most appropriate for reaching the translation goal in the given communicative situation.

Translation strategy is defined as a general program of the translator's activity worked out on the basis of the general approach to translation in a specific communicative situation (CS), determined by the particular parameters of the situation and the translation goal and, in its turn, determining the character of the translator's professional behavior.

Besides the immediate communication actors another actor is to be taken into consideration. Daniel Gile [Gile, 1991, p. 190] argues that an act of verbal communication occurring in a professional translation setting is triggered by an aim or intention. True, such an act can be triggered by an intention of any of the communication actors including the translator himself. Edwin Gentzler says that "a client who hires a translator has specific goals that need consideration; the receiving audience has certain expectations that need to be addressed" [Gentzler, 2001, p. 73]. But very often an act of translation is initiated by a person who is not immediately engaged in the cross-lingual communication but is still interested in positive outcomes of a specific act of communication across languages and cultures. The term "initiator" is applied to name such a person. The initiator's needs and expectations are also to be taken into account and duly respected by a translator.

Daniel Gile states that aims and intentions of the translation initiator and / or communication actors are multilayered, and explains that at the most superficial layer, an act of communication may aim at informing the Receiver of a fact; at deeper layers, it may aim at scoring a point in an intellectual debate through this information, at convincing the Receiver by scoring such points [Gile, 1991, p. 190]. Thus, immediate aim behind informational discourse segments can be: informing, explaining, convincing. When the Sender manages to achieve his / her aim, i. e. to inform, explain, or convince with the help of a mediator, (s)he thinks the communication to be successful. But this is a definition of the communication success only from the Sender's perspective. The translator is also expected to take account of the needs and expectations of the TT recipients and, in a broader sense, of any person(s) who perform(s) the role of the translation initiator, and, thus, to ensure the success of the 
translation act from the TT recipients' (and the initiator's) perspective.

It should be noted that in this paper the term "translation" is extended to denote both oral interpretation and written translation.

The communicative-functional approach first appeared in Western Translatology in 1970s-1990s, and now fights hard to dominate Translation Studies across the globe. The aim of this paper is to reveal the origins of this approach in Russian Translatology, to demonstrate how it developed from rare "epiphanies" to completed conceptions and theories, to a new and sophisticated way of thinking.

\section{Purely Linguistic Approach to Translation}

First, it should be noted that it was purely linguistic approach to translation that was dominant when Translatology was developed in Russia in 1950s-1960s. The fact is not surprising: due to the rapid development of comparative linguistic studies, translation scholars got interested in the translation aspects that related to peculiar interrelations of the languages that "collide" in the translation process. Incidentally, the situation was similar to that in the Western Translatology. Suffice it to recall the works by R. Jakobson, G. Mounin, J.-P. Vinai and J. Darbelnet and other scholars who felt it was their duty to investigate those semantic and structural differences between the languages that influence the translation process and its outcome, to describe and classify various transformations of the SL utterances in translation. It is noteworthy that in his Introduction to "Translation Theory” («Teoriya perevoda», 1990) Vilen Komissarov does not draw a hard-and-fast line between Western and Russian Translation Studies, and speaks of the common trends and tendencies in the both.

In Russia, it was Andrey Fyodorov who openly proclaimed the need to investigate translation on the basis of linguistics. In the early 1950s and later he argued that translation is "a creative activity related to language and literature and inevitably implying collision of two languages" (translation mine. - V. S.) [Fedorov, 1958, p. 15]. The appeal was heard and supported by Yakov Rezker who paid special attention to inter-lingual correspondences, which gave birth to his theory of regular correspondences [Rezker, 2007]. The purely linguistic approach to translation had many followers whose attention was focused on both correspondences and discrepancies between specific languages. The idea was very simple: such correspondences and discrepancies are bound to influence the translator's decision; they explain either the need for transformations or the lack of them. The essence of the linguistic approach is best summarized by Leonid Barkhudarov, another prominent translation scholar, who argued that Translation Theory must, first and foremost, determine correspondences and discrepancies between the means of expressing identical meanings in SL and TL, and on this basis to reveal the most regular ways of overcoming these discrepancies ("translation methods") [Barkhudarov, 1975].

The same approach was pursued by Vladimir Gak who stated that a translator deals with specific utterances in which words and grammatical forms express certain notions and relations which - in their turn - reflect certain phenomena of reality. It means that translation equivalence is based on the similarity of linguistic forms or on the same meanings of the units that differ in their forms or on the similarity of the situation described in the source text (ST) and the TT. On this basis Vladimir Gak differentiated between three models of translation (formal, semantic, situational) and three corresponding levels of equivalence [Gak, Grigoryev, 2000].

I want to make clear that reproduction of the content of the works written by the founders of Russian Translation Studies is not intended to reveal the roots of the communicative-functional approach to translation. Because there were none. I strongly believe that the purely linguistic approach pursued by the Translation Theory founders is not a convenient tool to reveal the essence of translation as a purposeful human activity. It investigates translation as if it is made in a vacuum, and represents it as a kind of "philological game": a translator allegedly substitutes units and forms of one language for units and forms of another language in accordance with rigid patterns, or algorithms, predetermined by the degree to which the linguistic units and grammatical forms in question coincide or differ in the two languages. Extra-lingual factors are totally disregarded, and the only guiding point and the quality criterion is 
the similarity of the semantic meanings of separate linguistic units (words, phrases or sentences).

I would like to add in passing that whole texts were rarely, if ever, used as material for translation analysis that time. The reason is obvious: in order to reveal substantial interlinguistic discrepancies which, at the same time, would be sufficient for uncovering translation problems it was enough to analyze units smaller than a text. In other words, a text was not seen as a tool of communication because communication is not a key notion in the framework of the purely linguistic approach to translation.

To be fair I should admit that in the works of the founders of the linguistic Translation Theory there are statements that might be very pleasant for those who adhere to functionalism in translation. For example, Yakov Rezker stated most unequivocally that Translation Theory must establish only functional correspondences with due account of the dependence of rendering semantic categories upon various factors [Retsker, 2007, p. 11]. In reality, the statement is not that inspiring as it might seem. After due scrutiny of the conception we come to the conclusion that the term "function" is applied by Rezker only to separate linguistic units, not texts. It is clearly evidenced by the following saying: "A linguistic form can perform different functions depending on a combination of various linguistic and extralinguistic factors" (translation mine. - V. S.) [Retsker, 2007, p. 12]. It is obvious that "linguistic form" cannot be applied to a text. Moreover, when a situation is mentioned it does not imply the situation in which communication between the ST sender and the TT recipient occurs and the TT is created. It merely implies the situation described in the two texts: "Both linguistic forms and elementary meanings expressed by them can be different in the two utterances which, nevertheless, describe the same situation" (translation mine. -V.S.) [Gak, Grigoryev, 2009, p. 11]. All this proves that Russian pioneers of Translation Theory remained in the grip of the purely linguistic approach to translation.

\section{Functionalism in Russia. Precursors of the Communicative-Functional Approach}

Yet, a thorough analysis of the writings of the Translation Theory pioneers reveals that they made attempts to unchain themselves from the purely linguistic approach. It is visible, most obviously, in the works by Vilen Komissarov, Alexander Schweitzer, Zinaida Lvovskaya, Ghelly Chernov and Lev Latyshev.

Vilen Komissarov was among the first translation scholars who attempted to investigate an act of translation within the framework of cross-lingual and cross-cultural communication. In his view, a translator is not merely a "transformer" of the SL texts (or even a SL utterance or unit). A translator is a mediator between people speaking different languages, the one who makes cross-lingual communication possible. Upon the whole, Komissarov's theory was not devoid of the heritage of the purely linguistic approach. I will go as far as to say that the theory is based upon this approach. It is noteworthy that the subtitle of his first large monograph contains the word-combination "An Essay on Linguistic Study of Translation” («Slovo o perevode (Ocherk lingisticheskogo ucheniya o perevode)») [Komissarov, 1973]. Yet, the "flashes" of functionalism that are gleaming in it have lighted up the path to the communicativefunctional approach. Among the "flashes" I can single out the term used to describe one of the levels of equivalence, specifically, the level of the "aim of communication", one of the five levels in the classification of interrelations between the ST and the TT [Komissarov, 1973]. From the functionalist perspective, the following statement is more important: "If we consider not a single utterance but a bigger message containing a number of utterances connected to each other, we can define the general aim of communication as an intention to make an impact on the Recipient, to impel him to some action, to trigger some reaction or to evoke associations" (translation mine. - V. S.) [Komissarov, 1973, p. 154]. At the time the statement was made, it was not just a glimmer in the distance; it was a glowing beacon spotlighting the way to functionalism. In his theory Vilen Komissarov took into consideration some extralingual factor that had been ignored by his predecessors. Among the factors we can single out the intention of the ST Sender ("to make an impact on the Recipient") and the peculiar features of the TT Recipient, his / her cultural background. It means that translation is observed as an activity 
which is expected to ensure the successful communication between the ST Sender and the TT Recipient. At the same time it should be noted that translation is investigated by V. Komissarov from the ST Sender's perspective only.

Despite all the merits of Komissarov's theory, especially when it is considered on the background of linguistic conceptions of translation, some contradictions in it can be observed. The most important one strikes the eye when we read how translation is defined. Vilen Komissarov argues that translation is a kind of linguistic mediation resulting in a TL text communicatively equivalent to the SL text, wherein the communicative equivalence of the TT is manifested in its functional, semantic and structural identification by the TT Recipient with the ST. Though the notion of "functional identification" is mentioned in the definition, the definition itself is based, undoubtedly, on the purely linguistic approach to translation. Nevertheless, the fact did not prevent the author to state immediately after defining the notion of translation - that "the communicative approach to translation is the main principle of modern Translation Studies" (translation mine. $-V$. S.) [Komissarov, 1990, p. 44-45].

No matter how contradictory Komissarov's theory is, it still contains ideas that have been used by other scholars in formulating the conception that is closer to what we call now the communicative-functional approach.

Alexander Schweitzer began his research of translation in accordance with the purely linguistic approach. It is not incidental at all that his monograph of 1973 is titled "Translation and Linguistics" («Perevod i Lingvistika»). Yet, the book contains a section on translation as an act of communication [Schweitzer, 1973, p. 61-76]. Highlighting the process of translation A. Schweitzer refers to the scheme offered by German scholar Otto Kade, and concludes that translation as an act of communication has two stages: 1) communication between the ST Sender and the Translator and 2) communication between the Translator and the TT Recipient. Besides, the Translator performs two roles: that of the receiver of the ST and that of the sender of the TT [Schweitzer, 1973, p. 63]. Since a text is viewed as a tool of communication, A. Schweitzer pays close attention to functional parameters of the text, specifically, to functions performed by it, referring to the classification of linguistic functions developed by R. Jacobson. He stresses that the text parameters are not incidental: they are predetermined by the goal of the text author, and ensure a certain impact on the text recipient. Perceiving these parameters, the text recipient gets a clue as to what the text author's intention is. A. Schweitzer says that the text author's communicative intention determines both the choice of the linguistic means and their specific density within an utterance [Schweitzer, 1988, p. 147]. Alexander Schweitzer's monograph "Translation Theory: Status, Problems, Aspects" («Teoriya perevoda: status, problemy, aspekty») of 1988 develops the functionalism ideas that were first voiced by him in the monograph of 1973. The author considers the following triad: 1) the communicative intention of the ST Sender, 2) the functional parameters of the text, 3) a communicative effect [Schweitzer, 1988, p. 147]. The notions introduced by A. Schweitzer into Russian Translation Studies are of paramount importance for the development of the communicative-functional approach. They helped form a vision of translation as a means of ensuring communication between actors who speak different languages, wherein the text serves as a tool of communication.

It is noteworthy that A. Schweitzer was under the influence of Eugene Nida who had introduced the notion of dynamic equivalence. A. Schweitzer fully shares the idea that equivalence of the two texts, the ST and the TT, must be based not on formal correspondence between them but on their functional correspondence. The latter, also termed "dynamic equivalence", is defined as a correspondence of the reaction of the TT Recipient to the reaction of the ST Recipient. Moreover, A. Schweitzer stresses that the reactions triggered by the two texts must conform to the communicative intention of the ST Sender. In this case the translation is thought to be adequate.

I stick to the idea that conformity of the Recipient's reaction, or a communicative effect, to the communicative intention of the ST Sender is a particular case, not always probable or desirable. In many situations it is not possible to ensure the effect envisioned by the ST Sender. For example, the reaction of the US Congress members to the address of the American 
President might be different from that of foreign countries' politicians or common people. In other situations the translation goal is simply different from that of the ST Sender. Suffice it to recall the so called "philological translation" of literary masterpieces which is not aimed at triggering the same reaction that has been triggered by the ST addressed to its original readers. But I do not intend to go into details of this issue now.

In passing, I'd like to note that describing translation as an act of communication, A. Schweitzer gives little clue as to why the communication actors get engaged into the act of communication. The actors' needs arising in connection with their personal and common substantive activity are not addressed. In other words, translation as a purposeful activity is not presented comprehensively. Still A. Schweitzer's contribution to formulating the communicativefunctional approach to translation can hardly be underestimated.

I believe that Zinaida Lvovskaya was the first to introduce the term "communicativefunctional approach to translation" into Russian Translation Studies [Lvovskaya, 1985]. She thought that the translation process comes down to reception and generation of speech. Therefore, in Translation Studies the points of departure must be searched for in the speech activity, i.e. at the level of communication [Lvovskaya, 1985, p. 75]. She substantiated the importance of investigating translation as a form of speech activity using the following provisions:

1. The final stage in the process of communication is deciphering the meaning of the text. The meaning can be comprehended by an interpreter only when linguistic factors are related to extra-lingual factors relevant in the given communicative situation. The correlation of linguistic and extra-lingual factors becomes distinct only at the communicative level.

2. To decipher the pragmatic value of the ST and to ensure the desired pragmatic value of the TT, it is necessary to take into consideration a number of extra-lingual factors such as cultural, historical, ethnic, social and other characteristics of the respective communities. Again, it is possible to do only at the communicative level [Lvovskaya, 1985, p. 76].

3. The principal criterion of the adequacy of the TT to the ST is their communicativefunctional equivalence [Lvovskaya, 1985, p. 76].
It is obvious that Z. Lvovskaya has extended the process of the interlanguage communication: it begins when the Sender originates the ST and is completed when the Recipient perceives the TT. What is most important is the fact that she called for observing both linguistic and extralingual factors that exert influence on the translation process.

But no less important is the fact that Z. Lvovskaya paid significant attention to the communicative situation in which the ST is originated and the TT is perceived. She says that formulating the content of the text and choosing linguistic means of its expression the Sender takes into account all formants of the communicative situation that are relevant in a particular case [Lvovskaya, 1985, p. 91]. The list of formants of the communicative situation includes: who, to whom, when, where, about what and why one speaks (writes), i.e. "the communicative situation results from such factors as the personality of the text author, the motive of his / her language behavior, the personality of the text interpreter, time and place of communication, the subject of speech" (translation mine. - V. S.) [Lvovskaya, 1985, p. 90]. These formants are heterogeneous in terms of their character, the information they bear and the significance of the information in the communication act. Therefore, two groups of formants are differentiated between and, accordingly, two situations: a situation of communication between the communication actors (the personality of the text author, his / her motive and aim, time and place of communication, the personality of the text interpreter) and a situation described in the text (what / who is spoken about, the time and place of the described actions / events, characteristics of people, objects and phenomena) [Lvovskaya, 1985, p. 92].

To Zinaida Lvovskaya's credit, she has extended the object of investigation by introducing such notions as the motive and aim of the text sender. She studied speech not as a phenomenon that exists by itself but as a tool of interaction between people. Producing a text as a tool of communication, the author assigns some communicative task to it. At the stage of interpreting the meaning of the text, the translator makes efforts to decipher this very communicative task and then, at the stage of text production, tries to produce a communicative effect in accordance 
with the communicative task stipulated by the text author. To do this, the translator has to take into account both objective differences between the ST recipients and the TT recipients (different cultural, ethnical and social background) and subjective differences (different interests, professions, political views, background and encyclopedic knowledge, individual tastes and preferences). The translator's task is to diminish this difference by means of transforming the semantic structure of the text, although in most cases the difference can hardly be annihilated completely [Lvovskaya, 1985, p. 155].

In my opinion, the Russian community of translatologists has not paid ample attention to the ideas voiced by Zinaida Lvovskaya. Yet, those ideas helped to form the minds of at least some scholars who later developed the communicativefunctional approach to translation.

The conception of $\mathrm{Z}$. Lvovskaya is concordant to that of Lev Latyshev though Latyshev's ideas are more distinctive and, for that very reason, exceptionally valuable to Translation Studies. In his view, translation is a mediation that satisfies the needs of society, not only the needs of individuals. I can say without any exaggeration that the notion of the "social purpose of translation" is a cornerstone of Latyshev's theory. The notion is defined in the following way: "Translation must enable the interlinguistic communication that, in terms of its possibilities, would be as close to ordinary, monolingual communication as possible" (translation mine. - V.S.) [Latyshev, 2000, p. 15]. It implies that the presence of the translator in communication must not be perceived by the communication actors. Another aspect of the social purpose of translation is revealed in the following statement: the TT must be perceived by the Recipient in a way (s)he would perceive the ST if (s)he could speak the source language [Latyshev, 1988, p. 10]. Translation is prevented from performing its mission (social purpose) by the linguistic-and-ethnical barrier. Moreover, any communication is hampered by differences in the world view, convictions, knowledge, life experience, habits and psychological peculiarities of the communication actors. These differences become even more pronounced in a situation of interlinguistic communication. The translator's task is to neutralize the effect produced by the linguistic-and-ethnical barrier by means of transformations that relate to the languages and cultures, without interfering into personal characteristics of the communication actors [Latyshev, 2000, p. 23].

Communication over the linguistic-andethnical barrier is aimed at exerting some influence on the TT Recipient, at triggering some reaction. In this respect the interlinguistic communication does not differ much from the monolingual communication. The expected reaction of the text recipient is the result desired by the text sender in the process of verbal communication [Latyshev, 2000, p. 20]. But Lev Latyshev admits that the identity of reactions to the ST and the TT by their respective recipients is an ideal which is not possible in reality. Therefore, he concludes that the equality of the effects produced by the ST and the TT is not based on the identical influences exerted upon the recipients; it is based - as far as possible - on the equivalence of the linguisticand-ethnical prerequisites of such an influence. Translation offers the ST and the TT Recipients equal possibilities of perceiving and interpreting the text in its original and translated forms (including a possibility to react similarly) while the actual reactions of the recipients depend on their individual characteristics [Latyshev, 1988, p. 21].

One of the requirements to the TT, according to Lev Latyshev, is to be a communicativefunctional equivalent of the ST. Communicativefunctional equivalence implies that the TT must potentially be able to exert regulatory influence on its recipient similar to that exerted by the ST upon its recipients. Another important point here is the enthronement of the text as a unit of translation. It was another step along the path to formulating the communicative-functional approach.

A large contribution to the development of this approach to translation was made by another Russia scholar, Ghelly Chernov. Investigating the process of simultaneous interpreting, he paid special attention to the factors, or formants, of the communicative situation of simultaneous interpreting. In his view, the main factors are revealed when we answer the following questions: 1) Who is speaking? 2) What is he speaking about? 3) Why is he speaking? 4) Whom is he addressing? 5) Where is he speaking? 6) When is he speaking? 7) What is he speaking for? 8) What has made him to speak? [Chernov, 1987, 
p. 109]. G. Chernov had no doubts that all these factors must be perceived, analyzed and taken into account by the interpreter in order to comprehend the communicative intention of the speaker, the communicative function of the text and the probable communicative effect to be produced by the speech. Undoubtedly, this vision of the communicative situation of the simultaneous interpreting is applicable to any other situation of translation / interpretation.

\section{Conclusion}

It is just natural that scientific investigation of translation began in Russia in accordance with the purely linguistic approach, which implied special and major attention to differences and correspondences between the two languages that "collide" in the translation process. Later on it dawned upon translation scholars that real translation problems did not arise from the "collision of languages": they result from the collision of SL and TL cultures. Transformations applied in translation must be treated as mere technicalities inherent in the translation process. Moreover, translation began to be viewed as a form of mediation between people who speak different languages but strive to understand each other. Investigation of translation as a form of mediation implied close attention to peculiar characteristics of both the ST Sender and the TT Recipient conditioned by their belonging to different language communities and cultures. As presented by the precursors of the communicative-functional approach, the ultimate aim of translation is to help the ST Sender realize his / her communicative intention as well as to ensure the production of a certain effect upon the TT Recipients in accordance with the ST Sender's expectations. It means that at the early stage of the communicative-functional approach development translation was viewed from the ST Sender's perspective.

It is noteworthy that the ideas expressed in the works of this approach precursors were developed rather independently, and with due account of the conditions in which translation is made in real life. It means that the precursors introduced common sense into Translation Studies. Though some aspects of translation remained unnoticed by the scholars I have mentioned, they managed to come closer to determining the essence of translation as human activity and to find solutions to some topical issues of Translation Studies. The most important result of functionalism in Translatology was the vision of translation as a purposeful activity that has nothing to do with the "philological game" of replacing units and structures of one language by units and structures of another language. Metaphorically speaking, translation acquired a "human face" in Russia in the 1970s-1980s.

True, it should be noted that Russian functionalists were not uninfluenced by their foreign colleagues, mostly by Eugene Nida, R. Jakobson and researchers of Leipzig translation school (O. Kade, A. Neubert). One of the most peculiar features of Russian Translation Studies is a complete neglect of the skopos-theory at a time it was heatedly discussed in the West. The skopostheory, though negatively treated by many Western scholars, still laid the foundation of the functionalist approach to translation in Western Translation Studies, as was brilliantly demonstrated by Erich Prunch [Prunch, 2015], and now exerts enormous influence upon formation of the communicativefunctional approach to translation in Russia [Sdobnikov, 2015]. It implies that the approach in question insistently fights its way to Russian Translation Studies. No less gratifying is the fact that recently some manuals have appeared in Russia (see, e.g., [Shlepnev, 2016; 2017]) in which translation is presented as a purposeful activity performed in accordance with this approach.

\section{REFERENCES}

Barkhudarov L.S. Yazyk i perevod: voprosy obshchey $i$ chastnoy teorii perevoda [Language and Translation: Issues of General and Special Translation Theory]. Moscow, Mezhdunar. otnosheniya Publ., $1975.240 \mathrm{p}$.

Chernov G.V. Osnovy sinkhronnogo perevoda [Fundamentals of Simultaneous Interpreting]. Moscow, Vysshaya shkola Publ., 1987. 256 p.

Fedorov A.V. Vvedenie v teoriyu perevoda: Lingvisticheskie aspekty [Introduction into Translation Theory: Linguistic Aspects]. $2^{\text {nd }}$ ed. Moscow, Izd-vo lit-ry na inostr. yaz., 1958. 376 p.

Gak V.G., Grigoryev B.B. Teoriya i praktika perevoda. Frantsuzskiy yazyk [Translation Theory and Practice. The French Language]. Moscow, Interdialekt+ Publ., 2000. 456 p. 
Gak V.G, Grigoryev B.B. Teoriya i praktika perevoda. Frantsuzskiy yazyk [Translation Theory and Practice: The French Language]. $9^{\text {th }}$ ed. Moscow, URSS Publ., 2009. 464 p.

Gentzler E. Contemporary Translation Theories. Revised $2^{\text {nd }}$ ed. Clevedon, Multilingual Matters Ltd., 2001. 232 p.

Gile D. A Communication-Oriented Analysis of Quality in Nonliterary Translation and Interpretation. Translation: Theory and Practice Tension and Interdependence: American Translators Association Scholarly Monograph Series, 1991, vol. 5, pp. 188-200.

Komissarov V.N. Slovo o perevode: Ocherk lingvisticheskogo ucheniya o perevode [A Word on Translation: An Essay on Linguistic Study of Translation]. Moscow, Mezhdunar. otnosheniya Publ., $1973.216 \mathrm{p}$.

Komissarov V.N. Teoriya perevoda: Lingvisticheskiye aspekty [Translation Theory: Linguistic Aspects]. Moscow, Vysshaya shkola Publ., 1990. 253 p.

Latyshev L.K. Perevod: problem teorii, praktiki i metodiki prevodavaniya [Translation: Problems of Theory, Practice and Methods of Teaching]. Moscow, Prosveshchenie Publ., 1988. 160 p.

Latyshev L.K. Tekhnologiya perevoda [Translation Technology]. Moscow, NVI-TEZAURUS Publ., 2000. 280 p.

Lvovskaya Z.D. Teoreticheskiye problemy perevoda (na materiale ispanskogo yazyka) [Theoretical Problems of Translation (On the Material of the Spanish language)]. Moscow, Vysshaya shkola Publ., 1985. 232 p.

Prunch E. Puti razvitiya zapadnogo perevodovedeniya. Ot yazykovoy asimmetrii $k$ politicheskoy [Ways of Development of Western Translation Studies. From the Language Asymmetry to the Political One]. Moscow, R. Valent Publ., 2015.512 p.

Retsker Ya.I. Teoriya perevoda $i$ perevodcheskaya praktika. Ocherki lingvisticheskoj teorii perevoda [Translation Theory and Translation Practice. Essays on the linguistic theory of translation]. Moscow, R. Valent Publ., 2007. 241 p.

Schweitzer A.D. Perevod i lingvistika (Gazetnoinformatsionnyy $i$ voenno-publitsisticheskiy perevod) [Translation and Linguistics (Newspaper and Information and Military-Journalistic Translation)]. Moscow, Voenizdat Publ., 1973. 280 p.

Schweitzer A.D. Teoriya perevoda: status, problemy, aspekty [Translation Theory: Status, Problems, Aspects]. Moscow, Nauka Publ., 1988. 215 p.

Sdobnikov V.V. Perevod i kommunikativnaya situatsiya: monografiya [Translation and Communicative Situation: Monograph]. Moscow, FLINTA, Nauka Publ., 2015. 464 p.

Shlepnev D.N. Obshchaya teoriya perevoda: Nachala. Chast 1 [General Translation Theory: Basis. Part 1]. Nizhny Novgorod, NGLU im. N.A. Dobrolyubova Publ., 2016.383 p.

Shlepnev D.N. Obshchaya teoriya perevoda: Nachala. Chast 2 [General Translation Theory: Basis. Part 2]. Nizhny Novgorod, NGLU im. N.A. Dobrolyubova Publ., 2017.272p.

\section{Information about the Author}

Vadim V. Sdobnikov, Doctor of Sciences (Philology), Associate Professor, Professor of the Department of the English Language and Translation Theory and Practice, Nizhny Novgorod State Linguistic University named after N.A. Dobrolyubov, Minina St., 31-A, 603155 Nizhny Novgorod, Russian Federation, sdobnik@lunn.ru, http://orcid.org/0000-0002-4717-2980

\section{Информация об авторе}

Вадим Витальевич Сдобников, доктор филологических наук, доцент, профессор кафедры теории и практики английского языка и перевода, Нижегородский государственный лингвистический университет имени Н.А. Добролюбова, ул. Минина, 31-А, 603155 г. Нижний Новгород, Российская Федерация, sdobnik@lunn.ru, http://orcid.org/0000-0002-4717-2980 